\title{
A comparison of Barkant turnips and Superchow sorghum for summer milk production
}

\author{
D.A. CLARK, S.L. HARRIS, E.R. THOM, C.D. WAUGH, P.J.A. COPEMAN and A.R. NAPPER \\ Dairying Research Corporation, Private Bag 3123, Hamilton
}

\begin{abstract}
Barkant turnips and Superchow sorghum were compared as summer-autumn crops for lactating cows, in a $2 \times 3$ factorial experiment fed at 3 levels $(0,4$ and $8 \mathrm{~kg} \mathrm{DM} /$ cow/day) to supplement pasture offered at a constant allowance of $25 \mathrm{~kg} \mathrm{DM} / \mathrm{cow} /$ day. Sixty lactating twin cows were used in 2 experimental periods in January and March 1996. Pasture and crop intakes were estimated by the alkane, and pre- and post-grazing, techniques. Feeding either 4 or $8 \mathrm{~kg} \mathrm{DM} /$ cow/day increased milksolids (MS) yield by $25 \%$ for turnips and $15 \%$ for sorghum compared with pasture alone. Turnips gave responses of 42.5 and $50 \mathrm{~g} \mathrm{MS} / \mathrm{kg}$ DM offered, at the lower allowance, in summer and autumn respectively; compared with $25 \mathrm{~g}$ MS/kg DM in both seasons for sorghum. Crop intakes were lower on sorghum than turnips and were only partially compensated for by increased pasture intakes on the former. For both crops, increasing allowance from 4 to $8 \mathrm{~kg} \mathrm{DM} / \mathrm{cow} /$ day did not increase daily MS yield. The cows grazing sorghum were 8 and $15 \mathrm{~kg}$ heavier than either the turnip or pasture-fed cows in summer and autumn respectively. Substitution rates for both crops were higher $(0.72-$ $0.87)$ in summer than in autumn $(0.35-0.45)$. This means that although both crops will have a "pasture sparing" effect in summer they will not contribute much to increased per cow intake.
\end{abstract}

Keywords: alkanes, crop intake, dairy cows, milksolids, milk yield, pasture intake, sorghum, turnips

\section{Introduction}

Key weaknesses of the New Zealand milk production system are: low milk production per cow, and a lack of consistency in milk composition and level of processing plant utilisation. A major area of concern is the reduced milksolids (MS) yield in summer-autumn. In the North Island, decline in milksolids in this period can be as high as $19 \% /$ herd/month compared with a theoretical decline of $7 \% /$ herd/month. Additional summer feed would improve milk yield, extend lactation and increase cow condition, enhance raw product consistency for processing and improve processing plant utilisation.

The growth of summer crops for milk production has a long history. Forage crops are utilised for supplementary feeding and as a means of preparing for pasture improvement. Two alternative crop types are brassicas and $\mathrm{C} 4$ green-feed crops such as sorghum and maize. Newer turnip cultivars have a high yield potential of 10-12 t DM/ha of high quality (11-13 MJ metabolisable energy (ME)/kg DM) over 80-120 days (Percival et al. 1986; Notman 1992). Superchow sorghum has a yield potential of 12-16 t DM/ha from 2-3 grazings with an energy content of $8.6 \mathrm{MJ} \mathrm{ME} / \mathrm{kg}$ DM.

This paper describes an experiment conducted at No 1 Dairy, Dairying Research Corporation (DRC) in 1995/96, the first experiment in a 3-year trial comparing Barkant turnips and Superchow sorghum for summerautumn milksolids yield.

\section{Materials and methods}

\section{Site and treatments}

Turnips were sown on two occasions, late October and late November 1995; sorghum was sown in early December 1995. Areas were sprayed with Roundup (4 1/ha) before cultivation. Superstrike Barkant turnip seed was broadcast sown at $2 \mathrm{~kg} / \mathrm{ha}$ with $500 \mathrm{~kg} / \mathrm{ha}$ of $30 \%$ potassic superphosphate; the crop was topdressed with $100 \mathrm{~kg} / \mathrm{ha}$ of urea 4 weeks after sowing. An initial sowing of Superchow sorghum on 21 November 1995 was a complete failure owing to Argentine stem weevil damage. On 2 December the failed crop was sprayed with Lorsban 40EC insecticide at 2.5 1/ha. Superchow sorghum seed was sown at $23 \mathrm{~kg} / \mathrm{ha}$ on 6 December with $500 \mathrm{~kg} / \mathrm{ha}$ of $30 \%$ potassic superphosphate; the crop was topdressed with $170 \mathrm{~kg} / \mathrm{ha}$ of urea 4 weeks after sowing. Part of the sorghum crop was harvested for silage on 19 January 1996. The experiment was a 2 $\times 3$ factorial, with the two crops fed at 3 levels $(0,4$ and $8 \mathrm{~kg} \mathrm{DM} / \mathrm{cow} /$ day) to supplement pasture offered at a constant allowance of $25 \mathrm{~kg} \mathrm{DM} /$ cow/day. There were 2 experimental periods in January and March 1996. 


\section{Animals}

In each experimental period 60 lactating monozygous twin cows balanced for current MS yield, age, breed, liveweight and stage of lactation were allocated to six treatment groups. Each experimental period was preceded by a uniformity period of 1 week when all cows grazed together on pasture and MS yield was assessed as a covariate. Following this covariate period, cows were introduced to their respective treatments for a week to allow time for them to adjust to the changed diet. In each experimental period there were two subperiods, each of 10 days. Cows remained on the same crop in both subperiods, but during the second subperiod they were allocated in a balanced fashion to one of the two feeding levels they did not use in the first subperiod. For example, of the 10 cows fed Barkant turnips at $8 \mathrm{~kg} \mathrm{DM} / \mathrm{cow} /$ day in subperiod 1,5 were allocated to Barkant turnips at $4 \mathrm{~kg} \mathrm{DM} / \mathrm{cow} /$ day and 5 to pasture only for subperiod 2. This design allowed MS response to different crop levels to be assessed by 2 replicate herds.

\section{Measurements}

Crop and pasture yield and composition: Crop yields were measured pre- and post-grazing by sampling 6 , $0.1 \mathrm{~m}^{2}$ quadrats on each occasion. Pasture yields preand post-grazing were estimated by taking 40 rising plate meter readings to measure height and then converting to $\mathrm{kg} \mathrm{DM} / \mathrm{ha}$ from standard calibration equations. Crops were dissected for leaf and bulb (turnip); leaf, sheath and stem (sorghum) and grass leaf and stem, clover and dead matter (pasture). Pastures and crops were analysed for in vitro organic matter digestibility (IVD), crude protein (CP), neutral detergent fibre (NDF) and acid detergent fibre (ADF).

Milk yield and composition: Individual milk yield and composition (fat, protein and lactose) were measured over the final 5 days of each subperiod.

Liveweight gain and condition score: Liveweight (LW) was measured weekly and condition score fortnightly.

Crop and pasture intake: Pasture intake was estimated by the alkane technique (Dove \& Mayes 1991) in summer and by pre- and post-grazing pasture plating in autumn, and crop intakes from pre- and post-grazing samples.

\section{Statistical analysis}

The data from each season were analysed as a $2 \times 3$ factorial cross-over design using the mixed models procedure in SAS. Two SEDs for comparison of interaction means are given, one for comparing means between different crops, and the other for comparing means on the same crop.

\section{Results}

\section{Chemical composition}

Turnips had lower NDF and ADF than either sorghum or pasture, and higher IVD (Table 1). Crude protein (CP) levels for both turnips and sorghum were below the 16-18\% recommended for lactating dairy cows (NRC 1985). Pasture CP was above the recommended level.

Table 1 Mean chemical composition (neutral detergent fibre (NDF)\%, acid detergent fibre (ADF)\%, in vitro digestibility (IVD)\%, crude protein (CP)\% and dry matter (DM)\%) of whole plant turnip, sorghum and pasture.

\begin{tabular}{lccc}
\hline & Turnips & Sorghum & Pasture \\
\hline NDF & 23.0 & 65.0 & 55.9 \\
ADF & 22.0 & 35.8 & 28.2 \\
IVD & 87.1 & 69.4 & 68.1 \\
CP & 12.0 & 9.6 & 19.7 \\
DM & 10.8 & 14.2 & - \\
\hline
\end{tabular}

\section{Crop total and component yields}

Turnip yields of $12.0 \mathrm{t} \mathrm{DM} / \mathrm{ha}$ were higher for the October-sown crop used in January, than the $7.5 \mathrm{t} \mathrm{DM} /$ ha for the November-sown crop used in March, but proportions of leaf and bulb were similar (Table 2). Sorghum yields of 7.7 and $7.1 \mathrm{t} \mathrm{DM/ha} \mathrm{for} \mathrm{summer}$ and autumn periods respectively were similar, despite the latter coming from regrowth after a silage cut. In both periods sorghum was flowering, or close to flowering when grazed, hence the high proportion of stem $(52.6 \%)$ recorded.

Table 2 Turnip and sorghum yields - component and total (t DM/ha).

\begin{tabular}{|c|c|c|c|}
\hline \multicolumn{2}{|c|}{ Crop/Component yields } & \multirow{2}{*}{$\begin{array}{c}\text { Turnips } \\
12.0\end{array}$} & \multirow{2}{*}{$\begin{array}{c}\text { Sorghum } \\
7.7^{*}\end{array}$} \\
\hline Whole plant & - summer & & \\
\hline & - autumn & 7.5 & 7.1 \\
\hline \multirow[t]{2}{*}{ Leaf and sheath } & - summer & 6.25 & 3.4 \\
\hline & - autumn & 4.33 & 3.1 \\
\hline \multirow[t]{2}{*}{ Stem } & - summer & - & 4.1 \\
\hline & - autumn & - & 3.7 \\
\hline \multirow[t]{2}{*}{ Bulb } & - summer & 5.74 & - \\
\hline & - autumn & 3.21 & \\
\hline
\end{tabular}

* includes sorghum flower. 


\section{Milk yield and composition}

In summer, there was a crop $\times$ allowance interaction on milk fat content $(\mathrm{P}<0.01)$ (Table 3$)$. Milk fat content from cows receiving the higher turnip allowance was lower than from all the other treatments. Milk protein content was higher on turnips $(3.66 \%)$ than on pasture $(3.56 \%)$ or sorghum $(3.57 \%)(\mathrm{P}<0.01)$.

In autumn, feeding turnips at either allowance decreased fat content from 5.56 to $5.25 \%$ ( $\mathrm{P}<0.001)$. A similar, but less marked trend occurred for sorghum, with a decline from 5.62 to $5.48 \%(\mathrm{P}<0.001)$. Turnips caused a larger fall in fat content than sorghum $(\mathrm{P}<0.001)$. Milk protein content was higher on the high allowance for both turnips and sorghum than either the low allowance or the pasture control $(\mathrm{P}<0.05)$.

In summer, turnip feeding gave a greater MS response than sorghum $(\mathrm{P}<0.001)$. For both crops there was a significant $(\mathrm{P}<0.001)$ quadratic relationship between MS yield and crop allowance. MS increased by 22 and $13 \%$ for turnips and sorghum respectively when fed at an allowance of $4 \mathrm{~kg} \mathrm{DM} / \mathrm{cow} / \mathrm{day}$, but did not increase when allowance increased to $8 \mathrm{~kg} \mathrm{DM} /$ cow/day.

In autumn, turnip feeding again gave a greater MS response than sorghum $(\mathrm{P}<0.001)$, and a quadratic relationship with allowance $(\mathrm{P}<0.001)$. MS increased by 28 and $15 \%$ for turnips and sorghum respectively at the lower allowance with no increase when $8 \mathrm{~kg} \mathrm{DM} /$ cow/day of crop was fed.

\section{Pasture and crop intake}

In summer and autumn crop intake increased with increasing allowance, but to a lesser extent than planned, especially for the sorghum (Table 4). In this crop, utilisation was only 50 and $66 \%$ of that offered in summer and autumn respectively. Pasture intake declined with increasing pasture allowance as expected. Total intake (pasture and crop) increased with increasing crop allowance.

Table 3 Effect of turnips and sorghum fed during summer and autumn on milk yield (I/cow/day), milk composition (fat\% and protein\%) and milksolids yield (kg MS/cow/day).

\begin{tabular}{|c|c|c|c|c|c|c|c|c|}
\hline \multirow[b]{2}{*}{$\begin{array}{c}\text { Allowance } \\
\text { (kg DM/cow/day) }\end{array}$} & \multicolumn{3}{|c|}{ Turnips } & \multicolumn{3}{|c|}{ Sorghum } & \multirow{2}{*}{$\begin{array}{c}\text { SED } \\
\text { Between } \\
\text { different crops } \\
\end{array}$} & \multirow{2}{*}{$\begin{array}{c}\text { SED } \\
\text { Between } \\
\text { different allow. }\end{array}$} \\
\hline & 0 & 4 & 8 & 0 & 4 & 8 & & \\
\hline \multicolumn{9}{|l|}{ Summer } \\
\hline Milk yield & 9.34 & 10.91 & 11.46 & 9.24 & 9.58 & 10.00 & 0.31 & 0.28 \\
\hline Fat\% & 5.13 & 5.04 & 4.89 & 5.10 & 5.14 & 5.12 & 0.07 & 0.06 \\
\hline Protein\% & 3.59 & 3.64 & 3.67 & 3.53 & 3.57 & 3.58 & 0.03 & 0.02 \\
\hline Milksolids & 0.76 & 0.93 & 0.94 & 0.76 & 0.86 & 0.88 & 0.02 & 0.02 \\
\hline \multicolumn{9}{|l|}{ Autumn } \\
\hline Milk yield & 8.13 & 9.99 & 9.95 & 7.70 & 8.60 & 8.72 & 0.28 & 0.20 \\
\hline Fat\% & 5.56 & 5.25 & 5.26 & 5.62 & 5.49 & 5.47 & 0.07 & 0.07 \\
\hline Protein\% & 3.83 & 3.85 & 3.96 & 3.90 & 3.85 & 3.90 & 0.03 & 0.03 \\
\hline Milksolids & 0.72 & 0.92 & 0.90 & 0.67 & 0.77 & 0.77 & 0.03 & 0.02 \\
\hline
\end{tabular}

Table 4 Effect of turnips and sorghum fed at different allowances during summer and autumn on intake ( $\mathrm{kg} \mathrm{DM} / \mathrm{cow} /$ day) measured by alkane (summer) or pre- and post-grazing (autumn) techniques.

\begin{tabular}{|c|c|c|c|c|c|c|c|c|}
\hline \multirow[b]{2}{*}{$\begin{array}{c}\text { Allowance } \\
\text { (kg DM/cow/day) }\end{array}$} & \multicolumn{3}{|c|}{ Turnips } & \multicolumn{3}{|c|}{ Sorghum } & \multirow{2}{*}{$\begin{array}{c}\text { SED } \\
\text { Between } \\
\text { different crops }\end{array}$} & \multirow{2}{*}{$\begin{array}{c}\text { SED } \\
\text { Between } \\
\text { different allow. }\end{array}$} \\
\hline & 0 & 4 & 8 & 0 & 4 & 8 & & \\
\hline \multicolumn{9}{|l|}{ Summer } \\
\hline Total intake & 10.52 & 11.33 & 12.62 & 10.38 & 10.33 & 11.60 & 0.31 & 0.32 \\
\hline Pasture intake & 10.52 & 7.60 & 6.64 & 10.38 & 8.37 & 7.50 & 0.36 & 0.38 \\
\hline Crop intake & 0.00 & 3.73 & 5.98 & 0.00 & 1.96 & 4.10 & - & - \\
\hline \multicolumn{9}{|l|}{ Autumn } \\
\hline Total intake & 8.80 & 11.28 & 13.00 & 8.80 & 10.10 & 11.95 & - & - \\
\hline Pasture intake & 8.80 & 7.40 & 6.50 & 8.80 & 7.50 & 6.60 & - & - \\
\hline Crop intake & 0.00 & 3.88 & 6.50 & 0.00 & 2.60 & 5.35 & - & - \\
\hline
\end{tabular}




\section{Liveweight gain}

The cows grazing sorghum were 8 and $15 \mathrm{~kg}$ heavier $(\mathrm{P}<0.001)$ than either the turnip- or pasture-fed cows in summer and autumn respectively.

\section{Discussion}

Both turnips and sorghum increased MS yield when offered at allowances of 4 or $8 \mathrm{~kg} \mathrm{DM} / \mathrm{cow} /$ day in either January (summer) or March (autumn). For turnips, the responses of 42.5 and $50 \mathrm{~g} \mathrm{MS} / \mathrm{kg}$ DM offered at the former allowance in summer and autumn respectively were similar to those of 36-39 g MS/kg DM offered in trials at Westpac Taranaki Agricultural Research Station (WTARS) and DRC reviewed by Clark et al. (1996). As in the present experiment, these trials showed little response when turnip allowance was increased above 4 $\mathrm{kg} \mathrm{DM} / \mathrm{cow} /$ day. For sorghum, when offered at $4 \mathrm{~kg}$ $\mathrm{DM} /$ cow/day, the responses were $25 \mathrm{~g} \mathrm{MS} / \mathrm{kg} \mathrm{DM}$ in both summer and autumn. No similar work with recent sorghum cultivars could be found.

The lower response from sorghum compared with turnips would be expected from the chemical composition (Table 1) and lower intake (Table 4). The much higher in vitro digestibility of turnips would be expected to give an increased ME content and hence higher milk yield, providing other factors such as protein or amino acids were not limiting. Calculations using crude contents of pasture, turnips and sorghum with estimated intakes show that turnip-fed cows would consume diets of 17.4 and $16.2 \% \mathrm{CP}$, and sorghum-fed cows, diets of 18.0 and $16.3 \% \mathrm{CP}$ at allowances of 4 and $8 \mathrm{~kg} \mathrm{DM} /$ cow/day in summer respectively. All are sufficient for the low level of MS produced in this trial and imply that energy rather than protein supply was limiting milk production.

The lower intake of sorghum compared with turnips in all treatments is probably a result of the low leaf content (approximately 20\%) of the sorghum and high stem content. Cows had obvious difficulty in prehending and consuming lower sorghum stems and the very high NDF levels in sorghum could be expected to reduce rate of passage and hence intake (Mertens 1987). However, despite these disadvantages, total intake for the sorghum treatments was usually above that of the pasture controls. However, pasture allowance was deliberately kept low to simulate a summer drought. The supplement effect of mature sorghum may be less marked at higher pasture allowances.

In contrast to the MS comparison, sorghum gave higher final LW in both summer and autumn than turnips. Turnip-fed cows failed to put on any more LW than the pasture-only cows. This agrees with other trials conducted recently at WTARS and DRC where turnips did not increase cow LW compared with pasture, although in one trial condition score was improved (Clark et al. 1996). The much greater fibre levels in sorghum compared with turnips (65\% vs $23 \%$ ) would have led to a higher acetate:propionate ratio. This would, in turn, have led to increased LW gain at the expense of MS production (Annison \& Armstrong 1970). However, data are not available to test this hypothesis.

Calculation of substitution rates (the decrease in pasture DM intake when $1 \mathrm{~kg}$ of DM crop is eaten) from Table 4 shows that during summer the substitution rate for turnips and sorghum was 0.72 and 0.87 respectively. This means that for each $\mathrm{kg}$ DM of sorghum consumed, pasture DM intake decreased by $0.87 \mathrm{~kg}$. Ideally, supplementary crops should have a substitution rate close to zero. During autumn, substitution rate for turnips and sorghum was 0.35 and 0.45 respectively. Therefore, both crops had a greater supplementary effect in autumn than in summer.

The large increase in turnip yield associated with late October compared with late November sowing confirms the results of a national survey of turnip yields that late October is the best time to sow for maximum yields (Clark 1995). The difficulty experienced in keeping sorghum in a vegetative state suggests that sowings should be staggered through DecemberJanuary and/or topping used to control flowering.

Recent work on turnips as a summer crop has led to conflicting recommendations. Notman (1992) suggested a break-even yield for turnips of $2.4 \mathrm{t} \mathrm{DM} / \mathrm{ha}$, based on partial budgeting; Clark (1995), using UDDER simulations, proposed break-even yields of 8 and $10 \mathrm{t}$ $\mathrm{DM} / \mathrm{ha}$ in dry or drought and normal years respectively. However, Exton et al. (1996), using a "split farm" technique, concluded that turnips were not a profitable crop based on trials done over 2 years on two farms in the Waikato, despite yields over $10 \mathrm{t} \mathrm{DM}$ /ha being achieved in the second year.

All of the above methods of evaluating the profitability of a summer crop can be criticised. The range of conditions under which a crop is grown is vast and the answer to the question "should I grow a summer crop for lactating cows?" will rarely be straightforward. Many farmers will grow a summer crop simply to prepare a better seed-bed as part of a pasture renewal programme. In these circumstances the information presented in this paper can be used to calculate what proportion of the farm should be renewed if crop is not to be wasted, what crops should be sown, and the optimum level of feeding.

\section{Conclusions}

Feeding of both turnips and sorghum to lactating dairy cows during both summer (January) and autumn (March) 
increased milksolids production compared with cows grazing pasture only. Turnips produced the bigger increase in production, although this was at least partly owing to the better utilisation of the turnip crop compared with the sorghum and therefore the higher total intakes. On both crops, there was no difference in milksolids yield between cows offered 4 or $8 \mathrm{~kg} \mathrm{DM} /$ cow/day despite differences in the actual amounts of crop eaten. This was owing to a combination of the compensatory increase in pasture intake at the lower crop allowance, and the poorer nutritional value of both the crops compared with pasture.

Both turnips and sorghum can increase summer and autumn milksolids yield when fed at up to $4 \mathrm{~kg} \mathrm{DM} / \mathrm{cow} /$ day, but there will be little response above this level. Sorghum is a more difficult crop to manage than turnips but is more suitable for late November-January sowing.

\section{ACKNOWLEDGEMENTS}

Thanks to staff at No. 1 Dairy, DRC for animal management and measurements, Roslyn McCabe and Vicki van Vught for assistance with crop and pasture sampling and Rhonda Hooper for statistical analyses.

\section{REFERENCES}

Annison, E.F.; Armstrong, D.G. 1970. Volatile fatty acid metabolism and energy supply. pp. 422-437.
In Physiology of digestion and metabolism in the ruminant. A.T. Phillipson (ed.). Oriel Press Ltd.

Clark, D.A. 1995. Summer milk - pasture and crops. Proceedings of the Ruakura Farmers' Conference 78: 10-16.

Clark, D.A.; Howse, S.W.; Johnson, R.J.; Pearson, A.; Penno, J.W.; Thomson, N.A. 1996. Turnips for summer milk production. Proceedings of the New Zealand Grassland Association 57: 145-150.

Dove, H. \& Mayes, R.W. 1991. The use of plant wax alkanes as marker substances in studies of the nutrition of herbivores: a review. Australian journal of agricultural research 42: 913-952.

Exton, P.R.; Dawson, J.E.; Thomson, N.A.; Moloney, S. 1996. More summer milk - progress to date. Proceedings of the Ruakura Farmers' Conference 48: $34-41$.

NRC 1985. Nutrients requirements of dairy cattle. Washington, DC, National Academic Press.

Mertens, D.R. 1987. Predicting intake and digestibility using mathematical models of ruminal function. Journal of animal science 64: 1548-1558.

Notman, P. 1992. Survey of turnip yield in Victoria, Australia. DRDC report.

Percival, N.S.; Bond, D.I.; Hunter, R.M. 1986. Evaluation of new forage brassica cultivars on the Central Plateau. Proceedings of the Agronomy Society of New Zealand 16: 41-48. 
